\title{
Study on Optimalization of Own-Source Revenue in Regencies and Municipals in Central Java Province
}

\author{
Jalu Aji Prakoso ${ }^{1}$, Suci Rahmawati Prima ${ }^{2}$, M. Chrisna Satriagasa ${ }^{3}$, M. Syahli \\ IMNS $^{4}$ \\ ${ }^{1}$ Magister of Economic Development, Faculty of Economics and Business, \\ Gadjah Mada University \\ ${ }^{2}$ Magister of Economic Development, FEB UGM; Faculty of Economics, \\ Andalas University \\ ${ }^{3}$ Faculty of Geography, Gadjah Mada University \\ ${ }^{4}$ Magister of Economics Development, Faculty of Economics and Business, Gadjah \\ Mada University \\ Email: JAPrakoso@gmail.com
}

\begin{abstract}
Optimizing the management of potential areas would provide additional revenue for the region. This research aims to assess whether the government in the counties and cities in Central Java province has been optimally manage their potentials so as to provide benefits increased local revenues derived from the wealth management area. Through the relationship between the variables of the original income (PAD) and the Gross Domestic Product (GRDP) in the counties and cities in Central Java is expected to be known whether each area has been optimal in obtaining local revenue. The data used is data revenues and GRDP in counties and cities in the province of Central Java during 2011-2013 from the Central Statistics Agency (BPS), the Supreme Audit Agency (BPK), Report of Realized $A P B D$, and RPJMD Central Java.

Methods of data analysis in this research is to use a simple linear regression analysis (OLS Model) and design analysis group. The analysis showed the existence of ties between the GRDP and the PAD. The magnitude of the relationship analyzed by simple linear regression, where the results indicate a positive trend.

The analysis showed that the GRDP value of the coefficient $b>b$ PAD either at the district, town and overall. These results indicate that there has been no attempt by the government to manage PAD so as to generate the GRDP increase. The government can manage the outcome of PAD to be used in a way that increases the GRDP obtained. As for the test results to determine differences in optimizing the management of local revenue between districts and cities showed that the district can generate GRDP is greater with smaller PAD. It shows that the effort made by the district is more efficient than the effort undertaken by the municipality.

Spatial analysis shows a comparison of the GRDP against the PAD in each county and city in Central Java province is divided into four clusters. Each cluster has a distinct regional characteristics seen from economic activity. The results of the socio-economic analysis of the economy in Central Java province when seen from the conditions of employment, which absorbs the most amount of power keraja is in the agricultural sector, which amounted to $31 \%$, followed by the trade sector $22 \%$ and industry $19 \%$.
\end{abstract}

Keyword: Decentralization, $P A D, G R D P$

JEL Classification: H72, O18 


\section{INTRODUCTION}

Implementation of Law No. 22 of 1999 on decentralization of authority from the central government to the local government supports independent era unfolded for local governance in Indonesia. Delegation of authority from the center applies both to the delegation of authority and delegation of financial management. The area has responsibility for financial management to achieve the welfare of society. Form of delegated authority of the financial sector is regulated in Law No. 33 of 2004, where there is a financial balance between the central government and local governments. Financial balance between the center and the area provides flexibility for regions in managing the potential of available resources.

The freedom to manage its finances to make one of the sources to increase local revenue. Regional income derived from the management area is a potential revenue (PAD), which may include the collection of taxes, levies, and other wealth management are separated. Optimizing the management of potential areas would provide additional revenue for the region. Current conditions, management of local revenue are performed in each region in Indonesia has not fully optimized. Evidently, from the value of central government transfers to local Planning Budget Expenditure $(\mathrm{APBN})$ in 2016 amounted to Rp.770,2 trillion or $36.8 \%$ of the total state budget. The amount of funds from the center to the area indicate that the region still rely on funding from the central support of the increased local revenues for local funding. Thus, to reduce dependence on local government financing by the central government takes effort to increase revenue sourced from the region. Through optimizing the management of existing resources in the local go- vernment areas expected to be able to increase local revenue.

Java island is an island with a high population density and has infrastructure more rapidly than other islands in Indonesia, but the data shows that the PAD are still many areas with a low level of revenue collection. Especially in Central Java province which has 35 districts and cities have three leading sectors of agriculture, mining and processing industry which will be the economic potential of the area that needs to be managed and used efficiently and effectively. Central Java province also has the infrastructure and wealth of natural resources than many other provinces in Java coupled with its strategic location allows high mobility of the population that should have PAD is high.

The increase in revenue is expected to push the budget allocation larger so that local governments can improve the quality of public services. But if polling PAD is optimal to do, how the management of PAD in each region, it is necessary to study the optimization of revenue collection in counties and cities in Central Java province.

\section{THEORETICAL FRAME WORK AND HYPOTHESIS Financial management}

Financial management is the overall activities that include planning, implementation, administration, reporting, accountability and financial control area (PP 58 of 2005). Financial management adheres to the principles of transparency, accountability and value for many. Transparency is a form of transparency in the process of planning, preparation and execution of local budgets. In this principle, members of the public have the same rights and access to know the budget process 
for the aspirations and common interests, especially the fulfillment of life.

As for the principle of accountability associated with public responsibility which means that the public budgeting process means that the budgeting process, from planning and preparation to implementation must be absolutely reportable and accountable to Parliament and the public. People not only have the right to know the budget but also the right to demand accountability for the im-plementation of the plan or the budget. While the principle of applying the principles of value for money, efficiency and effectiveness in the budgeting process.

Economics deals with the selection and use of resources in a certain quantity and quality at the lowest possible cost. Efficiency means that the use of public funds (public money) should produce the maximum output (empowering). Furthermore, the effectiveness means that the use of the budget must achieve the objectives of public interest.

\section{Own-Source Revenue}

According to Law No. 25 of 1999 which was then revised by Law No. 33 of 2004 on Financial Balance between Central and Local Government stated that the PAD, PAD is hereinafter referred to as the income collected Regional Regional Regulation in accordance with the legislation. PAD aims to give authority to local governments to fund the implementation of regional autonomy in accordance with the potential of the region as the embodiment of decentralization.

Regional Income is one source must always and continuously spur growth, because PAD is an important indicator to meet the level of independence of government in the financial sector. The higher the role of PAD to the budget, the more successful efforts of local governments to finance the implementation of government and regional development.

Revenue is earned income areas levied by local regulations in accordance with the legislation. In Article 6 stated that the source of revenue consists of local taxes, levies, wealth management outcomes separated areas, and others PAD legitimate. (Act No. 33 of 2004). Explanation of the PAD components are:

1) $\operatorname{Tax}$

2) According to Law No.28 of 2009 on Local Taxes and Levies Local Taxes, hereinafter called Tax, is a mandatory contribution to a region that is owed by private persons or entities that are enforceable under the Act, by not getting the rewards directly and used to the area for the purposes of the overall prosperity of the people

3) Levies

4) Levies, hereinafter referred levies, levies Regions as payment for services or certain special permits provided and / or granted by the regional government for the benefit of private persons or entities.

5) Results of Regional Wealth Management The Separated

6) Section profit enterprises is part of the profit or net income from regional companies or other entities which are public enterprises. While the regional companies is a company whose capital is partly or wholly a wealth of separated areas.

7) Other legal PAD

8) Revenue other than those mentioned above remain valid. This acceptance includes receipt of the rent of the local agencies, rental of buildings and land have local, current accounts, the sale of second-hand goods belonging 
to the region and other income authorized by law.

\section{Gross Regional Domestic Product}

Gross Regional Domestic

Product (G-RDP) is a macroeconomic indicators that can give an idea about the state of the economy of a region. In calcu-lating the Gross Regional Domestic Product (GRDP) that caused a region, there are three approaches used are:

a. The GRDP by production approach

b. Represents the total value of final goods or services produced by the various production units are located in an area within a certain period.

c. The GRDP by income approach

d. Remuneration is used by production factors which participate in the production process in a region within a certain time.

e. The GRDP by spending approach

f. Are all components of final expenses such as household consumption and private non-profit institutions, government consumption, gross fixed capital formation, stock change da in net exports in a given time.

GRDP can describe the ability of a local government to manage its natural resources. Therefore the amount of GRDP produced by each region relies heavily on the potential of natural resources and production factors of the area. There are limitations in the supply of these factors cause the amount of GRDP varies between regions.

GRDP at current prices illustrate the added value of goods and services is calculated using the price in the current year, while the GDP at constant prices shows the value-added goods and services calculated using prices prevailing in a given year as the base year. The GRDP according to current prices used to determine the ability of economic resources, shifts, and economic structure of a region. Meanwhile, the GDP constant used to determine economic growth in real terms from year to year or the economic growth that is not influenced by the price factor.

Optimizing the potential of the region to benefit the government as civil servants and the public. It is important to be a concern that the potential of each region can be optimized management, so as to benefit the region. This research aims to examine whether local governments have reached the optimal conditions in the management of revenue (PAD) in each county and city in the province of Central Java. By reviewing the conditions of regional revenue in each region it will obtain the real conditions on the financial condition of local government in Central Java Province.

\section{RESEARCH METHOD Population and Sample}

The population in this study is revenue (PAD) in the counties and cities in Central Java province. The sample in this study is the PAD districts in Central Java province in 2011-2013.

\section{Research Variable}

Variable in this study include variables such as revenue (PAD) and the Gross Regional Domestic Product (GRDP).

\section{Method of collecting data}

The data collection is done by collecting data from third-party providers of data related to this study. The data used in the study is the financial data in the form of the Budget Realization Report (LRA) government in 35 counties and cities in Central Java province obtained from the Supreme Audit Agency (BPK), condition data statistics counties and cities in Central Java province in the form of a report regional statistics released by the 
Central statistics Agency (BPS) in each region, and the Government's Medium Term Plan (RPJMD) Central Java Province. Data taken the form of data revenue (PAD) in 2011 to 2013 from the budget realization report, Gross Regional Domestic Product (GRDP) at constant prices in 20112013 of statistical reports each region.

Analysis Descriptive Statistics.

The analysis tool used is regression berganda.Jenis this research is descriptive quantitative research and use of spatial analysis that aims to explain a phenomenon that accompanied empirical statistical data, characteristics and patterns of relationships between variables. Analysis to see how the relationship between the GRDP and PAD then used a simple linear regression analysis with OLS model. OLS is a model used to examine the relationship two variables. Both of these variables associated with the equation:

$$
Y=\beta_{0}+\beta_{1}+\varepsilon
$$

So be obtained values of a and $b, b$ illustrates the value of each change of variable $x$ by one unit will affect the change of variable $y$ by $b$ unit. Optimization of effort is a component of the GDP. Effort can be seen from the coefficient $b$ assuming:

b GRDP $\leq$ b PAD make no effort, the effort does not increase the GRDP

$b$ GRDP > b PAD then there is effort, effort to increase the GRDP.

The design group is used to test the significant differences between the data collected. This design uses two different treatments. The two treatments are time and location. Samples are processed is the data the GRDP and revenue in 2011-2013 with:

H0: Data GRDP per capita and the

PAD did not differ significantly
H1: Data GRDP per capita and significantly different PAD

When, Fhit> Ftab reject H0, which means there is a time difference and different locations for the GRDP and revenue. Fhit $\$$ Ftab then fail to reject $\mathrm{H} 0$ which means there is no time difference and different locations for the GRDP and revenue.

\section{DATA ANALYSIS AND DIS- CUSSION Description Territory}

Central Java Province is a province located on the island of Java. The area is bordered by three other provinces, namely West Java, East Java, and Yogyakarta. In addition on the north and south, the area is bounded successively Java Sea and the Indian Ocean. Central Java Province has 26 districts and 6 cities spread on an area of $32801 \mathrm{~km}^{2}$. Central Java province has a population of 33.26 million in 2013 with a population density of 1,041 people $/ \mathrm{km}^{2}$ (CBS, 2014).

The area of Central Java Province of 2010 amounted to 25.04 percent of the size of Java (1.70 percent of Indonesia). Widely available, consisting of 992 thousand hectares (30.47 percent) of wetland and 2.26 million hectares (69.53 per cent) is not agricultural land.

Figure 1. Regional Studies

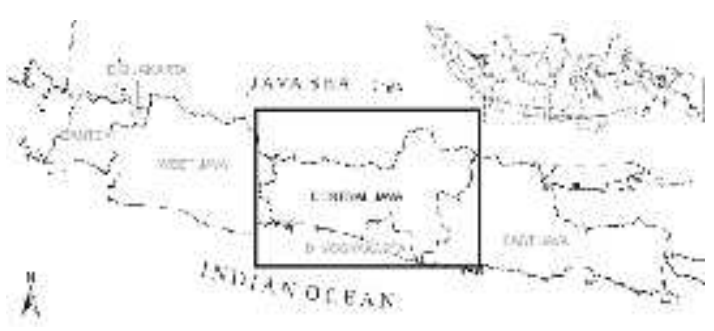

The population of Central Java in 2014 was recorded at 33.52 million approximately 13.29 percent of the total population of Indonesia. This 
puts the province of Central Java as Indonesia's third most populous after West Java and East Java. The population of women is greater than the number of males. This is shown by the sex ratio (the ratio of males to the number of females) amounted to 98.41 percent. Central Java's population has not spread evenly across the region of Central Java. Generally, many people accumulate in urban areas than districts.

On the average population density in Central Java in 2014 stood at 1,030 inhabitants per square kilometer, and the most populated area is the city of Surakarta with a density of more than 11 thousand people per square kilometer. Number of households amounted to 9.0 million in 2014 while the average population per household in Central Java was recorded at 3.7 inhabitants.

\section{Statistical Results}

PAD is a regional income tax sector, retribution, wealth management outcomes separated areas and other income native legitimate. PAD is used to finance the needs of the region to improve the facilities and infrastructure to support government activities aimed at improving the welfare of local communities, both directly and indirectly. Results PAD optimal reception is strongly influenced by the GRDP optimal. Areas that have high GRDP generally will increase the revenue gained. PAD and the GDP of the years 2011-2013 both in the districts and cities in Java (Figure 2).
Figure 2. GRDP and PAD county, city and district town in Central Java Province
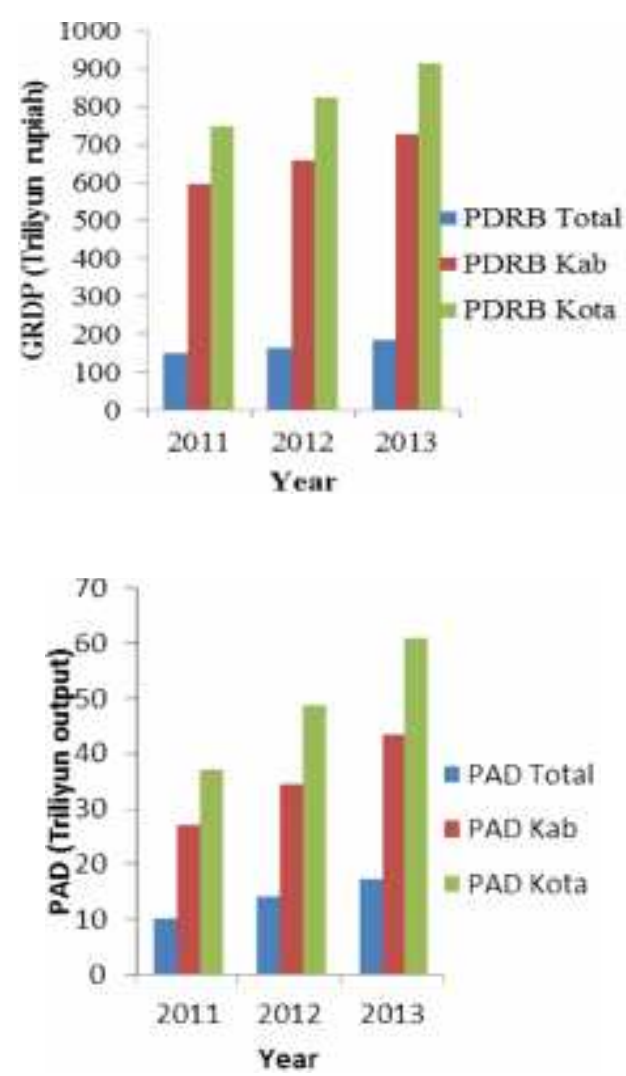

Source: BPS, 2014

Data processing is done on the GRDP data and PAD. GRDP relationship with PAD were analyzed using simple linear regression model with OLS. The results showed the presence of ties between the GDP and revenue by a positive trend (Figure 3 ).

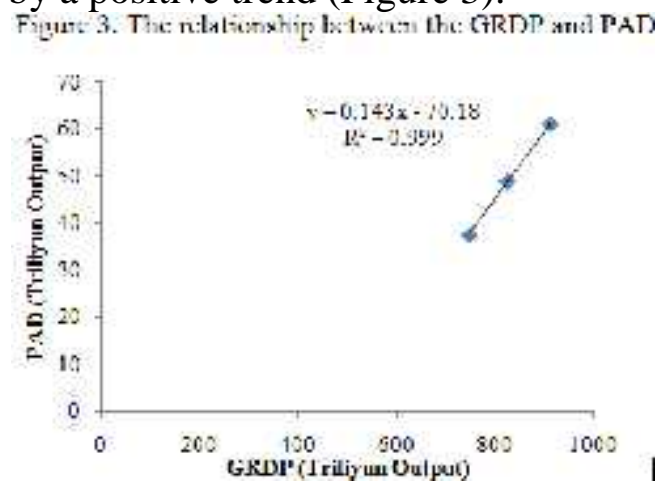

Source: Author, data proceed

Based on these images can be seen that any change in the GRDP of one unit will increase the revenue of 0.14 units. The coefficient of determination of $99.9 \%$ explained that the 
GDP variable can be explained by the variable revenue of $99.9 \%$, while $0.1 \%$ is explained by other variables. It also shows the close relationship between the GRDP and the PAD.

Effort is the effort made by the government to increase the GRDP of PAD results obtained. Effort was analyzed by comparing the value of the coefficient $b$ GRDP and coefficient $b$ PAD (Figure 4).

Figure 4. the GRDP (blue) and PAD (red) 2011-2013 (a) district (b) city (c) districts in Central Java Province

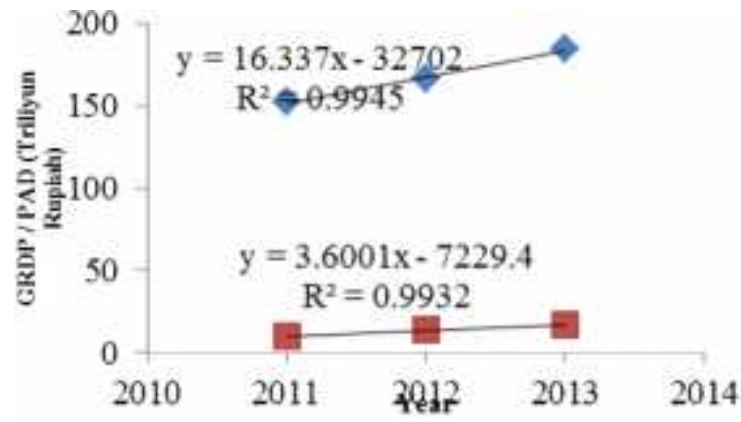

(a)

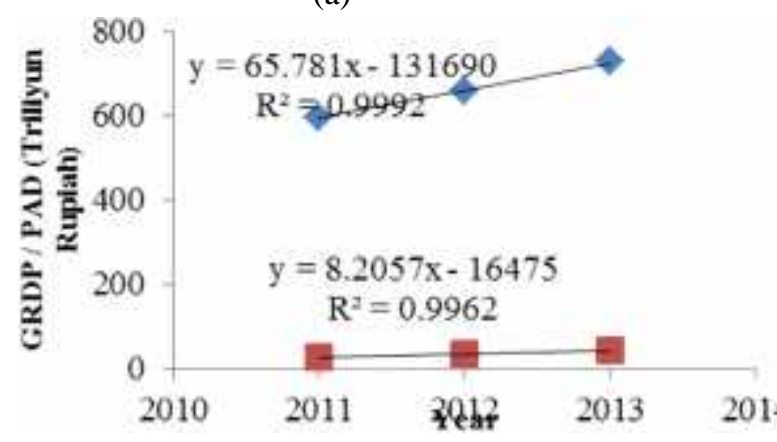

(b)

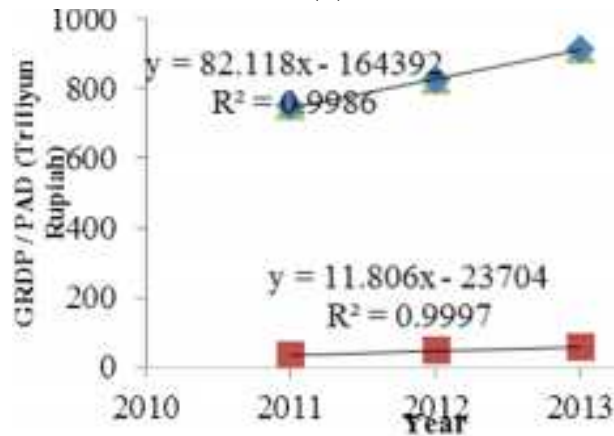

(c)

The analysis showed that the GRDP value of the coefficient $b>b$ PAD either at the district, town and overall. These results indicate that there has been no attempt by the government to manage the GRDP so as to generate added either directly or indirectly to the PAD. The government can manage the results of the GRDP to be used in a way that increases revenue obtained. The design group was conducted to see the difference between the GRDP and revenue in each location and at different times are presented in Table 1.

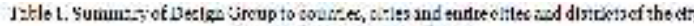
12.16t. Sum

\begin{tabular}{|c|c|c|c|c|c|}
\hline \multirow{2}{*}{$1 \cdots m+n$} & \multicolumn{2}{|c|}{ 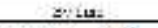 } & \multicolumn{2}{|c|}{$\underline{k}+\operatorname{sk} 2 \ln _{\mathrm{n}}$} & \multirow{2}{*}{ k:Ver } \\
\hline & $2: m=4$ & shes & sum-i & r sile & \\
\hline 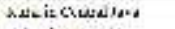 & $200,6<2$ & 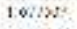 & $2,5: 5: 28$ & $5,123 \times 1$ & 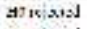 \\
\hline 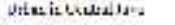 & $=23 . / 2 \%$ & $\therefore 22055$ & LISTAI & 1.23 .8 .1 & Alinjaied \\
\hline$\because \sin 2 \cdot x_{2} / 2$ & S2\%.NS: & $1 \mathrm{wt}: 23$ & $-4.344: 1$ & 5.152012 & Aligisi:] \\
\hline \multirow{2}{*}{ 1.2lais. } & \multicolumn{2}{|c|}{ int } & \multicolumn{2}{|c|}{ Ite cearm } & Jied \\
\hline & $z \mathrm{anu}$ & 5 laid & Eswan. & rsile & \\
\hline & $2-14 x$ & $10 \mathrm{FH}$ & $: 2,2=4$ & $3,6,29$ & istat \\
\hline Jitasisbuladsar- & $\therefore<N$ & $\therefore \ldots, 3$ & I.LS:1 & 1.228 & Al) injasted \\
\hline Sirtilisto & 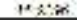 & $1 \mathrm{ml}:=$ & $m 123$ & ,11:18 & Himeret \\
\hline
\end{tabular}

The processed the GRDP and revenue showed that the value Fhit> Ftab every county, city and district town in Central Java Province. Fhit> Ftab reject H0. It shows there is a difference between the GRDP and the revenue obtained in a different location each year. Differences occur only data results in the treatment of differences in location to the GRDP. The results showed that there was no difference of GRDP is obtained between locations in Central Java for urban areas. The difference between 1 the district and the city showed in allocating revenue optimization to produce optimal PDRB.

The median is the most appropriate measure to see the distribution of data in case of error data is sizeable. Based on the processed data obtained that the district can generate GRDP is greater with smaller PAD. It shows that the effort made by the district is 2014 more efficient than the effort made by the city government. This is because the district has the optimal effort in establishing the sources of revenue blood than the city. Although the district has fewer sources of income, but 
efforts were made to pick it more optimal.

\section{Spatial Analysis}

Central Java province has 29 regions with district status and 6 regions with City status. Each area has characteristics that vary both from the physical characteristics of the environment, social and cultural characteristics, and the effort of the management area. Each of these characteristics contribute to the magnitude of the GRDP and PAD owned by each region.

As described previously, PAD is a local earned income levied by local regulations in accordance with the legislation consists of four sources, namely taxes and levies, Wealth Management results separated areas, and other legitimate PAD. Range of local revenue each district town in Central Java province showed considerable value width starting from Rp. 125756 million up to Rp. 930577 million. The value range is divided into 4 equalstep class uses methods so as to produce class 1 (Rp. 125756-202594 million) to grade 4 (Rp. 435599930577 million). Class 1 is a region belonging to the city districts with low local revenue, while grade 4 is the region with the largest revenue category.

Territories included in the category of class 1 to form a sizeable clusters in the central part of the province of Central Java. The region consists of of Purbalingga, Banjarnegara, Batang, Kendal, Temanggung regency, Magelang, Kota Magelang, Purworejo, Boyolali, and Klaten district. There are three separate areas of the cluster, namely Rembang, Blora Regency and Wonogiri. Entire city districts that fall within class 1 with PAD whose value is only less than or equal to Rp. 202594 million in 2013. The region was classified as grade 2 has PAD between Rp.202.595 million
- 279255 million. There are two clusters of territories included in this class, namely cluster western and eastern clusters. Cluster consists of the western region of Brebes, Tegal, Tegal, Pemalang and Pekalongan. While the eastern cluster consists of the District of Semarang, Demak, Jepara, Kudus, Pati regency, Grobogan, Sragen, Karanganyar, and Sukoharjo. There is only one area that is outside both these clusters are Kebumen.

Kota Surakarta, Cilacap and Banyumas included in the region with PAD class 3 with a magnitude of between Rp. 279256 million to 435596 million. The rest that Semarang has the highest PAD compared to other areas in Central Java province. Spatial distribution of PAD in Central Java province is presented in Figure 5.

Figure 5. Locally-Generated Revenue of each regional and municipal in Central Java Province 2013

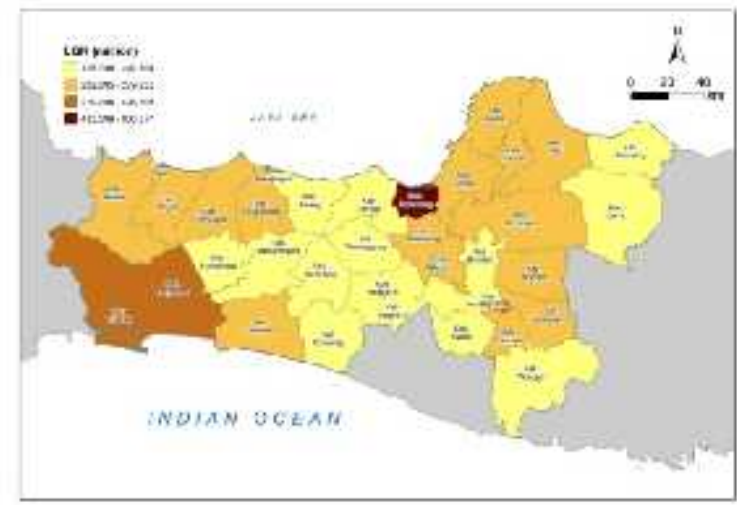

Figure 5 illustrates the spatial distribution of the GRDP in Central Java province. In contrast to the PAD, the GRDP is a macroeconomic indicator that can give an idea about the state of the economy of a region. One approach in measuring the GRDP the production approach. Under this approach, the region has indicated that the GRDP is greater in the region has a high economic activity. Range of local revenue each district town in Central Java province showed the 
value of a very wide starting from $\mathrm{Rp}$. 49874 hundred million to $\mathrm{Rp}$. 1025014 hundred million. This information explains that there are imbalances in economic activity fairly wide between the territory of the other regions in the province. On one side there are areas of activity the economy is very high, on the other hand there is a region which is so low that economic activity can only result in GDP is relatively small in a period of one year. In the region of Central Java Province GRDP of each region are classified into 4 classes. Class 1 (Rp. 49874-108929 hundred million) to Grade 4 (Rp.290.985-1.025.014 hundred million).

Territory belonging to the category of the GRDP smallest in the province of Central Java, Magelang City, Pekalongan, Salatiga, Tegal, Rembang, Purworejo, and Wonosobo. Most of the area is classified in this category is the region with the status of the city. The area of the city is much more narrow than the county, it is certainly one of the factors limiting economic activity in the region.

Territories included in the category groups grade PDRB 2 form two clusters located in the west and in the east. Western cluster consists of Tegal, Pemalang, Pekalongan, Batang, Purbalingga, Banjarnegara and Kebumen. While located in the eastern cluster, namely, Temanggung regency, Magelang, Boyolali, Grobogan, Demak, Jepara, and Blora. Wonogiri rest that are not included in any cluster.

Interrelation between regions in the category of grade 3 and 4 pretty looks of spatial patterns. Cilacap district, Semarang, Solo and Kudus is a region at the center of economy activity in Central Java province, it is apparent from the value of GRDP is the highest in the category. These areas are surrounded by the surroun- ding districts are quite dependent on economic activity. The areas surrounding the value of GRDP has category one level lower than its central region.

Figure 6. Gross regional Domestic Product of each regional and municipal in Central Java Province 2013

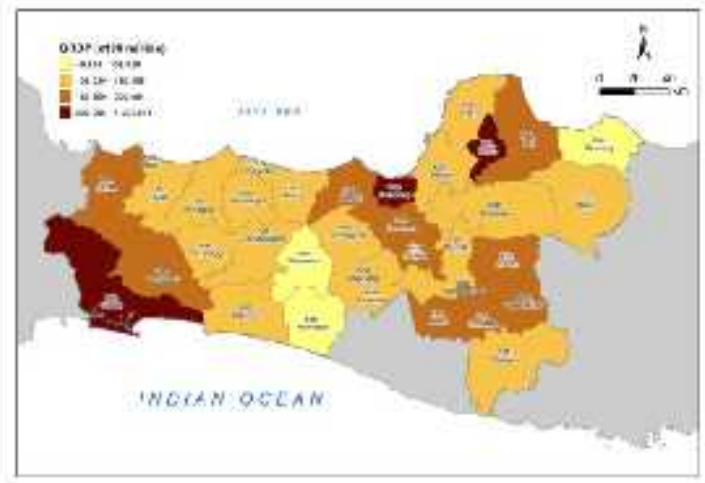

Source: Author, data proceed

To make the spatial analysis deeper for both LGR and GRDP in Central Java Province, leading sector data of each region were involved. Leading sector is main economic activity done inside the region or in the other way it contribute most in the region's GRDP. Central Bureau of Indonesia is divide economic sector into 9 sectors, there are agriculture; mining and quarrying; manufacturing industry; electricity, gas and water supply; construction; trade, hotel, and restaurant; transportation and communication; financial, owership, and business services; and services. According to the data, Central Java Province only has 3 type of leading economic activity sectors. Those sectors are processing industries; trading, hotel, and restaurant; and also agricultural sector. This data are presented spatially in figure 7 .

The spatial pattern of leading sector are similiar with GRDP. Region with agricultural-related economic activities as its leading sector were having medium to low GRDP as in Pemalang Regency, Purbalingga Regency, Banjarnegara Regency, Ke- 
bumen Regency, Wonosobo Regency, Purworejo Regency, Magelang Regency, Boyolali Regency, Grobogan Regency, Blora Regency, and Wonogiri Regency. While region with trading, hotel, and restaurant also processing industries as its leading sector were having medium to high GRDP as in Cilacap Regency, Kendal Regency, Semarang Regency, Semarang Municipal, Kudus Regency, Surakarta Municipal, Sragen Regency, Karanganyar Regency, Sukoharjo Regency, and Klaten Regency.

Figure 7. Leading Sector of each regional and municipal in Central Java Province 2013

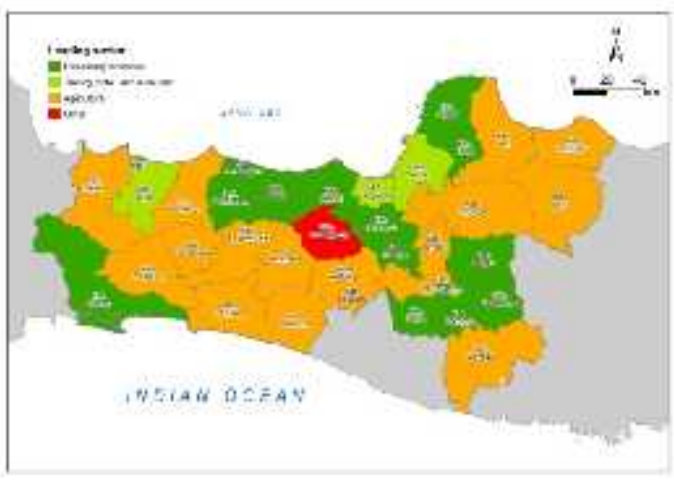

Source: Author, data proceed

Each region has a value of GRDP and PAD varies, so does the ratio between the two. The ratio of the GRDP and the PAD have meaning magnitude comparison between the two. The greater the numbers generated by these comparisons show that the GRDP has tremendous value compared to the $\mathrm{PAD}$ region, and vice versa. Spatial analysis is used to compare the ratio of the GRDP and revenue between regions in Central Java province, results of the analysis is presented in Figure 6 . The ratio between the GRDP and the revenue of each region in Central Java province has a wide range, from 30 to 268 . It this shows that there are variations in the ratio of the GRDP and PAD vary from area to area. This study divides the GRDP ratio and the PAD into four classes, ranging from grade 1 which has the lowest ratio (30-50) to grade 4 which has the highest ratio (143-268). In Figure 8, the area of class 1 with a ratio of between 30-50 is Pekalongan, Pekalongan, and Salatiga. Areas that are in this cluster has a ratio of the GRDP of the PAD is low. GRDP is lower in these clusters are influenced by economic conditions and regional areas. As Salatiga and Pekalongan, where the vast territory in both areas so small that the contribution to the value of GRDP is low.

Figure 8. GRDP and LEG ratio of each regional and municipal in Central Java Province 2013

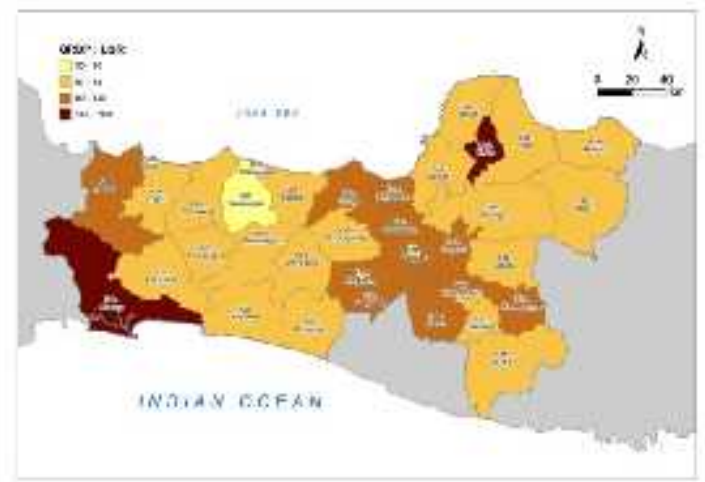

Source: Author, data proceed

Regional thinking about the status of the city mostly have a ratio of the GRDP and revenue is low, except Surakarta and Semarang. The region has the ratio of class 2 which has a ratio of 51-88 form two main clusters, cluster east including Jepara, Demak, Pati, Rembang, Grobogan, and Sragen. West cluster includes Tegal, Pemalang, Purbalingga, Banyumas, Banjarnegara, Kebumen, Purworejo, Wonosobo, Temanggung, and Batang. Besides these two main clusters, there are still Sukoharjo and Wonogiri belonging to cluster 2 .

These areas have a major activity in the agricultural sector as a pillar of the economy. The total area of agricultural areas that are in clusters 
of two tends to be broad. Productive agricultural land which are a potential area can be used by communities for agricultural activities which add value for farmers on agricultural land use.

The region has the third grade ratio to the ratio between $89-142$ only form one cluster that is Kendal, Semarang, Semarang, Magelang, Boyolali, and Klaten Karanganyar. Economic activity for Kendal, Semarang and Semarang district has the same diversity, because the location of the area of adjacent one another. The business sector which plays a role in the GDP of the area bnayak supported by the activities of services, especially in the city of Semarang. While other areas into the buffer zone of the city, where the buffer zones have benefited from business activities in the city. Magelang city has economic activity in the services sector and industry while and Magelang regency has economic activity agriculture and services sector. These activities contributed greatly to the GRDP for each region. For Klaten district, Karanganyar, Boyolali and the location of adjacent regions have the greatest economic activity of the agricultural sector and also supported by the industry Sekot. The number of inward investment into three regions results in more new jobs that can create jobs and maximize the potential of existing resources. Last wilaah Brebes be included in this cluster, where the main activity that play a role in the amount of GRDP comes from the agricultural sector.

Cilacap and Kudus has a very high rate. It is clear that this area has a high GRDP but PAD is low. Both of these regions have the value of GRDP is the highest among counties and cities in Central Java. The high value of GDP in the region is supported by the presence of a national industry with the scale stand up and operations carried out in the region. Cilacap, is the largest district in Central Java with a total area of 225,360.840 hectares (including reclaiming the island which has an area of 11551 hectares) are state-owned oil refinery industry so mempreoleh economic activity benefits from the industrial activities. Industrial excellence makes cilacap one of the three main industrial areas in Central Java (in addition to Semarang and Surakarta). Industry and trade sector that is able to absorb a lot of labor and contributed greatly to the GRDP. Kudus Regency is a small district that has a growing industry in the community either on a large scale, and small puff. Data obtained from Perindagkop in 2014 stated there are 12938 pieces of industrial enterprise / business unit in Kudus. The figure covers the entire company (business unit) industry both large / medium or small / household. So that the industrial sector contribute greatly to the value of GDP in Kudus.

\section{Socio-Economic Analysis}

Abdulsyani (1994) argues that "socio-economics is the status or position in society is determined by the type of economic activity, income level, education level, residential and office in the organization".Economic activity in Central Java province when seen from the conditions of employment, which absorbs the most amount of employment is in the agricultural sector, which amounted to $31 \%$, followed by the trade sector $22 \%$ and industry $19 \%$. The agricultural sector became the largest contributor to economic activity in Central Java because the area is still a lot of productive agricultural land.

Although, agricultural land every year productivity shrinkage extent because their agricultural land use transitions into a dwelling. 
Figure 9. Conditions for Economic Activity Based Jobs in Central Java Province

\section{Employment Sector}
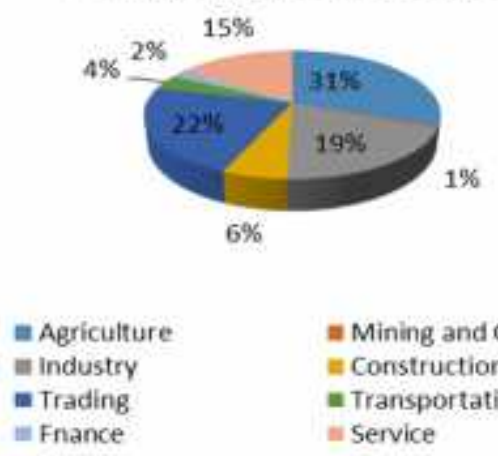

\section{CONCLUSION, IMPLICATI- ON, SUGGESTION, AND LI- MITATIONS}

Based on the results of the regression can be seen that any change of PAD as one unit will increase the GRDP by 6.9 units. The coefficient of determination of $99.9 \%$ explained that the GRDP variable can be explained by the variable revenue of $99.9 \%$, while $0.1 \%$ is explained by other variables.

Effort is the effort made by the government to increase the GRDP of PAD results obtained. The analysis showed that the GRDP value of the coefficient $b>b$ PAD either at the district, town and overall. These results indicate that there has been no attempt by the government to manage PAD so as to generate the GRDP increase.

The design group was conducted to see the difference between the GRDP and revenue in each location and at different times. The processed the GRDP and revenue showed that the value Fhit> Ftab every county, city and district town in Central Java Province. Fhit> Ftab reject $\mathrm{H} 0$. It shows that the effort made by the district is more efficient than the effort made by the city government.
The results of the spatial analysis showed that in Central Java province is divided into four clusters. Each cluster shows a comparison of the GRDP against the PAD condition. Cluster 1 consists of three regions, clusters 2 form distribution patterns, namely the eastern cluster consisting of six regional and western cluster consists of 10 regions, cluster 3 is composed of seven regions, and cluster 4 consists of 2 areas.

Economic activity in Central Java province when seen from the conditions of employment, which absorbs the most amount of power keraja is in the agricultural sector, which amounted to $31 \%$, followed by the trade sector $22 \%$ and industry $19 \%$.

Area counties and cities in Central Java province has had effort / effort to increase revenue. In order to further increase revenue in the region, it is necessary for local optimization and efficiency in the management of potential champions in each region.

Urban areas must pay attention to efficiency in revenue collection efforts. One effort that can be made to perform efficiently in voting PAD is with the use of technology for collecting the revenue associated with services. Since, the city has more business in services.

\section{REFERENCES}

Abdulsyani. (1994). Sociology and Society Change. Jakarta: Pustaka Jaya

Baban, S. (2003). Strategy optimization of revenue (pad): the case of Banjarmasin city, 34, 18.

Deddy, K. (2001). Map of the financial capacity of the province in the era of regional autonomy: Performance Review of the PAD, and Initiatives by Region, 12. 
Hadi, S. (2009). Analysis of Regional Autonomy Autonomy: The Case of Malang (1999-2004). JESP, one (1), 14.

Ilhayul, Ulum, M. (2006). Analysis of Investment Attractiveness Rating Relationships with Local Revenue (PAD) Regency / City in Indonesia. JAKSP, 7, 11 .

Central Bureau of Statistics. (2014)

Central Java Semarang in 2014.

Figures: Statistics Central Java

Province.

Government Regulation 58 Year 2005 on Regional Financial Management

Law No. 22 of 1999 on decentralization of authority from the central government to the regional governments.

Law No. 33 of 2004 on Financial Balance between the Central Government and Local Government.

Law No. 28 Year 2009 on Regional Taxes and Levies 